\title{
Older adults living in social housing in Canada: the next COVID-19 hotspot?
}

\author{
Melissa Pirrie ${ }^{1}$ (D) $\cdot$ Gina Agarwal ${ }^{1,2}$ (D) \\ Received: 31 August 2020 / Accepted: 30 November 2020 / Published online: 4 January 2021 \\ (C) The Canadian Public Health Association 2021
}

\begin{abstract}
Older adults in social housing have high rates of chronic diseases and live in clustered housing, creating the ideal situation for a tragic outbreak in this vulnerable population, which has been largely unrecognized in the public health discourse. It is estimated that two thirds of this population have cardiometabolic conditions that put them at higher risk of poor outcomes from COVID-19. In addition, their social isolation, low mobility, low health literacy, and limited internet access are barriers to accessing basic needs, health information, and health care in a Canadian context where many services have moved to virtual platforms. Since older adults in social housing tend to be clustered in apartment buildings with shared facilities, there is an increased risk of exposure through common spaces (e.g., elevator, laundry room) and high-touch surfaces. Compared to long-term care homes, there is substantial movement in and out of social housing buildings as residents are required to go out to meet their basic needs and individuals providing support enter the buildings without screening (e.g., personal support workers, volunteers delivering groceries). Without a targeted public health strategy to support this vulnerable population, we surmise that social housing will be the next COVID-19 hotspot.
\end{abstract}

\section{Résumé}

Les adultes âgés en logement social présentent des taux élevés de maladies chroniques et vivent dans des logements regroupés, une situation propice à une éclosion tragique dans cette population vulnérable largement laissée pour compte dans le discours de la santé publique. Il est estimé que les deux tiers de ces adultes ont des troubles cardiométaboliques qui les exposent davantage aux résultats défavorables de la COVID-19. En outre, leur isolement social, leur faible mobilité, leur faible littératie en santé et leur accès limité à l'Internet font obstacle à la satisfaction de leurs besoins fondamentaux et à leur accès aux renseignements médicaux et aux soins de santé dans un contexte canadien où de nombreux services ne sont maintenant offerts que sur des plateformes virtuelles. Comme les adultes âgés en logement social tendent à être regroupés dans des immeubles d'appartements avec des installations communes, les espaces communs (ascenseur, salle de lavage) et les surfaces souvent touchées leur font courir un risque d'exposition accru. Comparativement aux maisons de soins de longue durée, il y a de nombreux va-et-vient dans les immeubles de logements sociaux, car les résidents doivent sortir pour satisfaire leurs besoins fondamentaux, et les personnes qui les aident (préposés aux services de soutien à la personne, bénévoles qui livrent des produits d'épicerie) entrent dans l'immeuble sans être assujetties à un contrôle. En l'absence d'une stratégie de santé publique pour appuyer cette population vulnérable, nous présumons que les logements sociaux seront le prochain «point chaud » de la COVID-19.

Keywords COVID-19 $\cdot$ Social isolation $\cdot$ Health literacy $\cdot$ Seniors $\cdot$ Social housing $\cdot$ Multimorbidity $\cdot$ Vulnerable populations

Mots-clés COVID-19 $\cdot$ isolement social $\cdot$ littératie en santé $\cdot$ aînés $\cdot$ logement social $\cdot$ multimorbidité $\cdot$ populations vulnérables

Gina Agarwal

gina.agarwal@gmail.com

1 Department of Family Medicine, David Braley Health Sciences Centre, McMaster University, Hamilton, ON L8P 1H6, Canada

2 Department of Health Research Methods, Evidence and Impact, McMaster University, Hamilton, Canada

\section{Introduction}

Coronavirus disease 2019 (COVID-19) outbreaks have occurred disproportionately in vulnerable populations in Canada (Public Health Agency of Canada 2020). The majority of deaths since March 2020 have been in long-term care homes (Public Health Agency of Canada 2020). These are 
congregate living settings where the SARS-CoV-2 virus can spread like wildfire without rigorous infection control practices due to the opportunity to be transmitted through common surfaces or care-workers, and through droplet spread. Also, the risk of mortality from COVID-19 is high since almost all residents have multiple chronic diseases (Ontario Long Term Care Association 2016), which are known to increase the risk of mortality from COVID-19 (Kim et al. 2020). However, there is another setting where older adults with higher than average chronic disease rates reside in close quarters: social housing buildings.

Social housing is rent-geared-to-income housing (e.g., apartments, townhouse complexes), managed by municipal and regional housing providers, where the rent is typically $30 \%$ of household income and subsidized by the government. While seniors are generally considered to be individuals aged 65 and over, many social housing providers have designated 'seniors-only' buildings and use eligibility criteria for tenancy as low as 55 years old, depending on the region. Therefore, we will use the term "older adults" when referring to individuals living in seniors' social housing. We postulate that this setting of seniors' social housing buildings is at high risk for future clusters of COVID-19 outbreaks.

\section{High-risk population with potential barriers to accessing basic needs and health care}

Our social housing data from 3390 older adult residents in 17 Ontario municipalities/regions suggests that $83 \%$ have at least one cardiometabolic condition; in particular, $67 \%$ report having hypertension and 30\% diabetes (CP@clinic 2019). A COVID-19 surveillance study in the United States suggests that admission to intensive care was significantly higher $(p<0.05)$ for those 50-64, 65-74, 75-84, and 85 years and over than for those 18-39 years of age (adjusted relative risk [aRR] 1.53, 1.65, 1.84, and 1.43, respectively), and in-hospital mortality was also higher for these same age categories (aRR 3.11, 5.77, 7.67, and 10.98, respectively) (Kim et al. 2020). The same study found that in-hospital mortality was significantly higher for individuals with a history of cardiovascular disease (aRR 1.28) and diabetes (aRR 1.19) (Kim et al. 2020). Residents of seniors' social housing are also more likely to be frail since 19\% have difficulties with self-care (e.g., dressing), $34 \%$ have difficulties with performing usual activities (e.g., housework, leisure activities), and 64\% have pain or discomfort (CP@ clinic 2019). In addition, the health of this population is very precarious due to their limited resources, challenges accessing basic necessities, and low health literacy. Even before the COVID-19 pandemic, 52\% had poor mobility (CP@ clinic 2019) and social isolation (lack of social connectedness) was a common experience (Agarwal and Brydges 2018). During the pandemic, while many individuals in the general population have turned to internet-based solutions to access health care (e.g., virtual primary care visits) (Favaro and St. Philip 2020), to fulfill their basic needs (e.g., grocery apps) (Saba 2020), and to stay connected with friends and family (Weichel 2020), this may not be an option for older adults in social housing. Among low-income seniors in Canada, only $45 \%$ of those aged 65-69 years have internet access (compared to $97 \%$ in higher income brackets), and internet access drops to $12 \%$ for low-income seniors over 80 years old (Davidson and Schimmele 2019). Beyond these technological limitations, $82 \%$ of older adults in social housing have poor health literacy (Agarwal et al. 2018) and traditional health-related messaging may be ineffective. Together, these factors increase the likelihood that older adults in social housing will face greater challenges than other populations in accessing health care, health information, and basic needs, while keeping themselves safe at home.

\section{Clustered living conditions in many social housing buildings}

In Ontario alone, there are 70,000 low-income seniors (aged 65 and over) living in social housing buildings (Ontario NonProfit Housing Association 2016), which are often mid- and high-rise apartment buildings with shared facilities. Without the ability to use internet-based tools to meet their needs, these individuals may leave their apartments more frequently, such as going to the lobby to collect mail (e.g., paper-based bills) or leaving the building for appointments and groceries. In addition, this population cannot stock up on groceries due to restrictive incomes and need to leave their homes to buy food more often. In this setting, there is a higher likelihood of infection exposure in common areas (e.g., elevators, lobby, laundry room, garbage/recycling room) through interaction with many high-touch surfaces (e.g., door handles, elevator buttons, washer/dryer). In Calgary, Alberta, elevators are the suspected vector where more than 50 cases have been identified in a single high-rise building (Franklin 2020). Meanwhile, in Australia, nine high-rise social housing buildings were fully quarantined due to a sudden surge of 23 COVID-19 cases within 24 hours that could have rapidly spread further had residents not been required to stay within their units (Wahlquist and Simons 2020). In both of these cases, the buildings had a mixed resident populationyounger adults, older adults, and children - and there have been no fatalities to date; if these had been seniors-only housing buildings, the results could have been far worse due to underlying health conditions, general frailty, and poor health literacy (Kim et al. 2020; CP@ clinic 2019; Agarwal et al. 2018). 


\section{Lack of public health measures tailored to this vulnerable population}

Although both older adult residents of seniors' social housing and long-term care residents have underlying risk factors (age, multimorbidity) and are clustered together, they differ in how they have been protected by public health measures. In longterm care, at times of heightened risk for COVID, the residences have been completely locked down, so the only movement in and out of the buildings is by staff members who are being actively screened and have been trained in infection control protocols (Ministry of Long-Term Care 2020). These measures have been mandated by the provincial government and employers. The residents are also less mobile, with more than a third being entirely dependent on nurses and personal support staff for care (toileting, eating, etc.) (Ontario Long Term Care Association 2016). In contrast, social housing residents are routinely venturing out into the community for necessities. This leads to risk of exposure to the SARS-CoV-2 virus, potentially becoming infected, and possibly infecting others through high-touch surfaces or spending time in communal indoor spaces. In addition, individuals who are not employees of the housing provider may be entering the premises to provide needed support (e.g., volunteer groups delivering groceries, personal support workers) and there is no screening process for individuals entering housing buildings. Therefore, risk of exposure to COVID-19 for social housing residents should be a matter of concern. We would surmise that Canada has been fortunate that seniors' social housing buildings have not yet had an outbreak; however, without careful monitoring and adequate resources, this may be the next setting for a devastating COVID-19 outbreak.

\section{Implications}

To date, the focus of containment and control activities has largely been around long-term care facilities. In the moment of crisis, seniors' social housing may have been overlooked as medical officers of health struggle to contain emergent situations. However, as the pandemic continues, health inequalities in vulnerable populations have become more evident (Bambra et al. 2020). Persistent physical distancing coupled with the cancellation of regular health and social programming renders them even more susceptible to adverse health effects. Older adult residents in social housing are already socially isolated and pandemic control measures may be disproportionately affecting them (Mishra et al. 2020). There needs to be a concerted effort around supporting these individuals through heightened infection control as well as measures to mitigate the unintended consequences, not just as a preventive measure but in an ongoing way.
Having older adults in high-density buildings is both a risk and a benefit when facing a pandemic - these settings provide an opportunity to efficiently deliver services and potentially reduce some of the negative consequences of COVID measures, but these efforts need to be implemented in a manner that minimizes the potential for infection. A delicate balance needs to be maintained. For example, many housing providers provide onsite laundry rooms, which improves accessibility to this basic need but can also increase the risk of being in close proximity to other residents for a sustained period of time. Strategies to avoid viral spread in this setting can include cohorting residents (e.g., each floor has a designated day of the week), ensuring proper ventilation (e.g., open windows, air filtration), providing sufficient funding for housing providers to increase the frequency of cleaning, and providing residents with free masks, gloves, and sanitizer. Similarly, when feasible, social programming could be implemented to curb social isolation while being respectful of infection control measures (e.g., advanced sign-up, physically distanced, wearing masks, handwashing/sanitizer, and appropriate cleaning). This programming could include social activities, such as bingo, but also important opportunities for directly communicating public health information to a population with low health literacy (Agarwal et al. 2018). Recognizing the rapidly increasing need for internet access, housing providers could supply building-wide internet service, enabling connections to virtual healthcare and other online resources, though this would require investment from local and provincial governments to support this initiative on a large scale. Another strategy could be the co-location of home care and other services in social housing, which would facilitate continuity of care and more efficient delivery to residents within the building while reducing external exposures. Finally, for larger apartment buildings, mechanisms for contact tracing could be devised to help stop the spread as quickly as possible if a case is identified (e.g., resident, visitor, volunteer). In essence, social housing represents a 'vertical cruise ship', and if public health strategies for containment do not focus on efforts in this sector, there may be many more fatalities to come in the next waves.

Author contributions MP and GA conceived and wrote the commentary. All authors approved the final version.

\section{Compliance with ethical standards}

Conflict of interest The authors declare that they have no conflict of interest.

\section{References}

Agarwal, G., \& Brydges, M. (2018). Effects of a community health promotion program on social factors in a vulnerable older adult 
population residing in social housing. BMC Geriatrics, 18, 95 . https://doi.org/10.1186/s12877-018-0764-9.

Agarwal, G., Habing, K., Pirrie, M., Angeles, R., Marzanek, F., \& Parascandalo, J. (2018). Assessing health literacy among older adults living in subsidized housing: a cross-sectional study. Canadian Journal of Public Health, 109(3), 401-409.

Bambra, C., Riordan, R., Ford, J., et al. (2020). The COVID-19 pandemic and health inequalities. Journal of Epidemiology and Community Health. https://doi.org/10.1136/jech-2020-214401.

CP@clinic. (2019). Our story. Hamilton: McMaster Community Paramedicine Research Team. https://cpatclinic.ca/our-story/. Accessed 1 Nov 2020.

Davidson, J., \& Schimmele, C. (2019). Evolving internet use among Canadian seniors. Ottawa: Statistics Canada. https://www150. statcan.gc.ca/n1/pub/11f0019m/11f0019m2019015-eng.htm. Accessed 31 Aug 2020.

Favaro, A., \& St. Philip, E. (2020). Ontario implements virtual medical visits in bid to keep doctors, patients safe amid COVID-19. CTV News. https://www.ctvnews.ca/health/coronavirus/ontarioimplements-virtual-medical-visits-in-bid-to-keep-doctors-patientssafe-amid-covid-19-1.4853436. Accessed 31 Aug 2020.

Franklin, M. (2020). More than 50 cases of COVID-19 connected to Calgary condo building. CTV News. https://calgary.ctvnews.ca/ more-than-50-cases-of-covid-19-connected-to-calgary-condobuilding-1.5008655. Accessed 31 Aug 2020.

Kim, L., Garg, S., O'Halloran, A., et al. (2020). Risk factors for intensive care unit admission and in-hospital mortality among hospitalized adults identified through the U.S. Coronavirus Disease 2019 (COVID-19)-Associated Hospitalization Surveillance Network (COVID-NET). Clinical Infectious Diseases, ciaa1012. https://doi. org/10.1093/cid/ciaa1012.

Ministry of Long-Term Care. (2020). COVID-19 action plan: long-term care homes. Toronto: Government of Ontario. https://www.ontario. ca/page/covid-19-action-plan-long-term-care-homes. Accessed 31 Aug 2020.

Mishra, S., Kwong, J. C., Chan, A. K., et al. (2020). Understanding heterogeneity to inform the public health response to COVID-19 in Canada. CMAJ, 192(25), E684-E685. https://doi.org/10.1503/ cmaj.201112.

Ontario Long Term Care Association. (2016). This is long term care 2016. Toronto: Ontario Long Term Care Association. https:// www.oltca.com/oltca/documents/reports/tiltc2016.pdf. Accessed 31 Aug 2020.

Ontario Non-Profit Housing Association. (2016). FocusON: aging in place in social housing. Toronto: Ontario Non-Profit Housing Association. https://www.ighhub.org/sites/default/files/FocusON\% 2520 Aging $\% 2520$ in $\% 2520$ place $\% 2520$ in $\% 2520$ social $\%$ 2520housing.pdf. Accessed 31 Aug 2020.

Public Health Agency of Canada. (2020). From risk to resilience: an equity approach to COVID-19. Ottawa: Government of Canada. https://www.canada.ca/en/public-health/corporate/publications/ chief-public-health-officer-reports-state-public-health-canada/fromrisk-resilience-equity-approach-covid-19.html. Accessed 1 Nov 2020

Saba, R. (2020). Facing 'overwhelming demand,' grocery chains warn of food-delivery delays. The Star. https://www.thestar.com/business/ 2020/03/24/facing-overwhelming-demand-grocery-chains-warn-offood-delivery-delays.html. Accessed 31 Aug 2020.

Wahlquist, C., \& Simons, M. (2020). Melbourne's 'hard lockdown' orders residents of nine public housing towers to stay home as coronavirus cases surge. The Guardian. https://www.theguardian.com/ world/2020/jul/04/melbournes-hard-lockdown-orders-residents-ofnine-public-housing-towers-to-stay-home-as-coronavirus-casessurge. Accessed 31 Aug 2020.

Weichel, A. (2020). Canadians most excited to hug friends, dine out once COVID-19 restrictions lifted: poll. CTV News. https://bc.ctvnews. ca/canadians-most-excited-to-hug-friends-dine-out-once-covid-19restrictions-lifted-poll-1.4895994. Accessed 31 Aug 2020.

Publisher's note Springer Nature remains neutral with regard to jurisdictional claims in published maps and institutional affiliations. 